\title{
The ECONOMICS OF REgIONAL ECONOMICS ASSOCIATIONS
}

\author{
by
}

\author{
John J. Siegfried
}

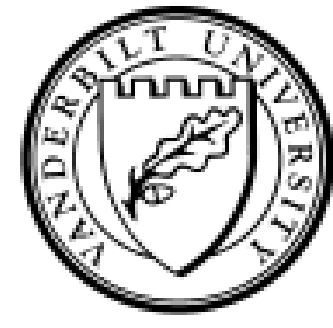

Working Paper No. 01-W15

August 2001

\section{DEPARTMENT OF ECONOMICS \\ VANDERBILT UNIVERSITY \\ NASHVILLE, TN 37235}

www.vanderbilt.edu/econ 
The Economics of regional Economics Associations

John J. Siegfried*

\begin{abstract}
Membership and conference attendance trends of regional economics associations are reported and analyzed. Although membership and conference attendance grow steadily at the American Economic Association, both are stagnant for the regional associations. Membership elasticity for economics associations ranges from -0.25 to -0.50 ; conference attendance is very inelastic with respect to registration fees. While the regional associations may find it challenging to grow, they have the capacity to expand revenues if that should be necessary to survive.
\end{abstract}

*The author is Professor of Economics at Vanderbilt University and SecretaryTreasurer of the American Economic Association. This essay was his presidential address to the Midwest Economics Association, March 30, 2001. Elton Hinshaw (American Economic Association), Joe Jadlow (Southern), Mary Lesser (Eastern), Mark Montgomery (Midwest), and Anil Puri (Western) helped develop this paper through a two day discussion of many of these issues. Aubrey Smith provided extraordinary research assistance and many ideas that improved the paper. Hnshaw, Jadlow, Ben Bloch, and Malcolm Getz provided helpful comments on an earlier draft. 
Professional associations play an important role in the work lives of many economists ${ }^{1}$. The professional association structure in economics consists of one major national association-the American Economic Association--four larger established regional economics associations-the Southern Economic Association, the Western Economic Association, the Midwest Economics Association, and the Eastern Economic Association--several smaller regional associations--for example, the Missouri Valley Economic Association and state economics associations--a number of national field specific associations--the Industrial Relations Research Association, the Econometric Society, the Industrial Organization Society, the Cliometrics Society--and a number of regional field specific associations--the Midwest Econometrics Group, the Southeastern Theory Group, etc.

In this article I consider some economic issues related to the four established regional economics associations. I will occasionally use the American Economic Association as a benchmark. Three of the regional associations were formed before World War II, the Western in 1922, the Southern in 1927, and the Midwest in 1934. This was a period when travel was dominated by trains rather than planes. The Eastern Economic Association began in 1974.

The Southern, Western, and Eastern associations each publish a journal ${ }^{2}$. The Midwest Economics Association is affiliated with the Quarterly Review of Economics and Finance, but does not publish it, and membership in the Association does not include a subscription to the journal.

Each of the regional associations organizes an annual domestic conference ${ }^{3}$. The Southern conference is usually in November, the Midwest and Eastern in March or April, and the Western in June or July. The Western association currently has a membership of about 2,000; 
the Southern about 1,000, the Eastern about 700, and the Midwest about 500. The annual budget of the Western Economic Association currently is about $\$ 600,000$, the Southern about $\$ 250,000$, the Eastern about $\$ 100,000$, and the Midwest about $\$ 50,000$. As a benchmark, the AEA currently has a membership of about 20,000 and an annual budget of about $\$ 5$ million.

\section{Membership Trends}

Membership in the three regional economics associations that pre-date World War II has been stagnant or declining in recent decades. Membership in the Southern has fallen approximately 25 percent since 1974. Membership in the Western has declined about 15 percent since 1982. The largest drop, however, has been experienced by the Midwest Economics Association, which has suffered a decline in membership approaching two-thirds since $1982^{4}$.

In contrast to stagnant or declining membership in regional associations, AEA membership has increased from around 18,000 in the mid 1970 s to about 20,000 today. This modest rise is consistent with a fairly steady level of new entrants into the profession. New Ph.D.'s awarded in economics have ranged between 850 and 950 for most of the last quarter century, while the number of Ph.D. economists reaching the typical retirement age of 65 has remained under 300. The proportion of faculty who are members of the AEA has remained fairly constant, ranging between 74 and 79 percent from 1955 through 1995 (Siegfried, 1998).

AEA membership has shifted geographically, however (Smythe, 1999). Since 1969, the AEA's membership has moved from the East and Midwest to the South and West. As Table 1 shows, the largest reallocation has been from the Midwest to the South. The absolute number of AEA members in the Midwest actually has declined over the past quarter century.

The declining number of economists living in the Midwest cannot account for all of the 
decline in the Midwest association's membership over the past two decades, however. Indeed, the Southern and Western associations also lost members during the period, yet the relative share of economists in their regions of the country grew. There seems to be no escaping the conclusion that regional economics associations are in decline, apparently playing a less important role in the professional lives of economists today than they did in the 1960s and 1970s.

\section{Demand for Regional Economics Associations}

To investigate the declining interest in regional economics associations I first consider the sources of demand for membership. Beyond the choice of service mix and quality standards, the supply side of the market is unlikely to explain much of the membership slide. The regional associations pretty much blanket the country. They do not compete directly in many areas, although the establishment of the Eastern Association in the 1970s may have diverted the allegiance of a few economists residing in Pennsylvania, Delaware, and Maryland from the Midwest and Southern Associations ${ }^{5}$.

More importantly, short run supply is almost perfectly elastic. None of the associations is close to enrolling all eligible members and each will take as many new members as are interested and willing to pay the existing dues. Beyond paying

dues, there are virtually no other requirements for membership in the associations ${ }^{6}$.

The regional associations provide two principal services. Each publishes or is affiliated with a general interest economics journal, and each organizes an annual convention held in its region. The demand for both of these services appears to be derived from a demand for information and a demand for recognition. I consider each of these in turn. 
The journals. Economists read economics journals to learn about new research findings that may be useful in their own research or that may be otherwise useful in their jobs. Academic economists frequently look for articles that can be used in teaching, either as a direct assignment, or as input for the instructor's personal interpretation and conveyance to a class. General journals are more likely to publish such articles than field journals because articles in general journals more frequently are self contained, describing in detail the question being considered and what was previously known about it, how the present research advances our understanding, the methodological approach, the source(s) of information, the results, and the importance of the findings for other economic research and for public policy. In contrast, articles in field specific journals often de-emphasize the first and last of these components--the "why are we doing this" and "who cares" parts of the story. As a result, articles in general journals more frequently read like a story, including a beginning, a middle, and an end, and are therefore less intimidating to students who are unfamiliar with the background literature and do not understand the issuespecific jargon.

One possible explanation for the decline in membership in the regional associations, then, is that their journals have veered away from a traditional role of publishing research contributions directed toward generalists. If this were true, those generalists would lose interest in the journals. Anecdotal evidence suggests, however, that the style of articles in he Southern

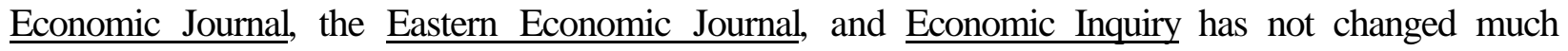
since the 1970s.

Alternatively, substitutes for general interest economics may have improved. With the focus of faculty and deans on national reputations, the American Economic Review, Journal of Political Economy, and Quarterly Journal of Economics have surged ahead in terms of citations 
and reputation, reflecting, in part, the more general phenomenon of winner-take-all markets evolving from dramatic changes in communication technology. In addition, the Journal of Economic Perspectives began publishing in the mid 1980s. It has captured a lot of space on course reading lists that might have otherwise gone to articles appearing in regional general interest journals.

Another explanation for declining membership, of course, is that the demand for general interest economics has declined. As scholarship has progressed and communication costs have declined, the net return to specialization may have increased. If that is the case, increasingly specialized economists may find less and less of the content in new issues of generalist journals to be relevant. If so, they will be less willing to pay the dues necessary to receive those journals.

Economists also demand journals as an outlet for their own research, as an affirmation of the quality of their professional work, and as a means of professional recognition. Thus, the demand, in some part, comes from those who produce the articles published by the journals, not unlike Roger Noll's explanation of the demand for intercollegiate athletics rising from a quest by college students for recognition and credentials that set them apart from other students (Noll, 1999). Substitute vehicles for disseminating research results and affirming the quality of research would, then, diminish the demand for the general journals published by the regional economics associations.

There is no question that the number of field specific economics journals has grown substantially over the past quarter century. Many of these newer journals quickly acquired considerable stature. Because of the overall growth in economics journals, relatively fewer economists publish in the regional associations' general journals today. In addition, the regional 
associations' second-tier general interest journals have lost relative stature. Ellison (2000)finds a dramatic decline from 1980 to 1998 in the rate at which articles appearing in second tier general interest journals are cited relative to the rate at which articles in the top general interest journals are cited. Consequently, fewer economists are likely to join the associations that offer second-tier general interest economics journals as a member benefit.

The meetings. Economists attend conventions for various reasons (Siegfried and Nelson, 1979). The annual convention provides an opportunity to present research findings to one's professional colleagues and receive constructive criticism, to observe the frontiers of economic research, to meet old friends, to discuss professional issues with colleagues at other institutions, to generate research ideas, to re-live the "good old days" of graduate school with old friends, to gossip about the profession with anyone who will listen, sometimes to have one's employer pay for a vacation that would have been taken anyway, periodically to participate in the labor market for economists, to examine new books and software first hand at the publishers' exhibits, to honor distinguished colleagues, and occasionally to have egos inflated or crushed.

A survey in the late 1970 s found that conferees at four professional business conventions reported spending an average of 46 percent of waking hours in professional activities such as meetings, seminars, and discussions with professional colleagues, 30 percent spent in social activities, and 21 percent seeking employment or recruiting (Thompson, Gaedeke, and Tootelian, 1979). Data from the Allied Social Science Associations convention reveal that on average 25 percent of registrants attend sessions during each of the nine session slots. About a third of ASSA registrants are actively seeking a job, and almost 40 percent are involved in interviewing job applicants at some time during the meetings.

Clearly, a bt of time at conferences is occupied by activities other than attending sessions 
or interviewing for jobs, and a lot of that is what the computer age has dubbed "networking." Hotel lobbies at both the ASSA meetings and regional economics conventions host many informal discussions. One of the most popular activities at the annual ASSA meetings is the receptions hosted by economics departments from 6 to $8 \mathrm{pm}^{7}$. Disentangling the social aspect of cocktail discussions from professional networking at the receptions would be impossible, however.

A very important service of conventions is the opportunity to present a paper. Not only might the author receive comments from a discussant with interests and research experience on the topic of his or her paper, but a convention presentation also provides professional exposure. Ultimately "reputation" is one of the things that universities ask their faculty to maximize. In some cases, especially if the program is selective, a presentation may serve to verify the quality of a faculty member's research. This is more likely to occur at the AEA meetings than at regional conventions, because the acceptance rate for individually submitted papers to the AEA program hovers around 10 percent, while that at regional meetings fluctuates widely, but probably averages closer to 90 percent.

Regional conferences face a dilemma with respect to program selectivity. The more selective they are, the more valuable is a spot on the program if the selectivity can be incorporated into the reputation of the meetings. However, as program standards are tightened and more papers rejected, relatively

more potential registrants are excluded from the program and the financial viability of the convention is put at risk.

A recent survey at the AEA meetings found that about 25 percent of registrants are 
reimbursed for travel only if they are "on the program." Another 30 percent are eligible for reimbursement whether they are on the program or not. The remaining 45 percent are ineligible for reimbursement. Potential registrants at regional economics associations are more likely to qualify for reimbursement contingent on a program appearance, and frequently only if they present a paper. Regional conventions attract fewer economists who can tap special research accounts to cover travel costs. Regional conventions also attract fewer job candidates, who constitute a large portion of those whose expenses are not reimbursed by their employer at the ASSA meetings.

Opportunities to appear on the ASSA program grew rapidly over the last several decades. The program doubled from 227 sessions in 1978 to 549 sessions in 1998 . With the greater prestige associated with an appearance on the program of a "national convention," and with a limited travel budget or number of trips per year, regional conventions must have lost priority to the ASSA meetings over the past two decades. This, in turn affects membership in the regional associations because each of them offers a bundled convention registration and association membership at a lower price than the sum of the two purchased separately.

Over the longer run, declining travel costs, both in terms of time and money, have made the ASSA convention a better substitute for regional meetings. After the economic deregulation of airlines in 1978, the relationship between air fares and travel distance gave way to a stronger relationship between fares and market power, so that it now costs much less to fly from Nashville, Tennessee to Los Angeles or Chicago than to Atlanta, St. Louis, or Cincinnati. As the connection between travel cost and distance eroded, so too did some of the relative cost advantage of regional association conventions. Today only those economists within driving distance of a convention realize substantial travel cost savings, although this may still make 
some difference ${ }^{8}$.

Finally, a changing labor market for Ph.D. economists has not been friendly to the regional associations' conferences. Job Openings for Economists began operating in 1975, and quickly came to dominate listings of jobs for economists. In fulfilling its goal, JOE broadened the labor market for economists, thereby reducing the value of regional contacts between hiring department chairs and faculty at nearby Ph.D. producing universities. $\quad$ JOE led to a more "national" market, and increased the mobility of economists, if only between their graduate alma mater and their first job.

The job market at the annual ASSA meetings has grown dramatically over the past several decades. Because of network economies and declining transportation costs, it has developed into the dominant time and location in the world to hire economists ${ }^{9}$. Another university with which I am affiliated, the University of Adelaide in South Australia, annually interviews job candidates primarily from Canada, Europe, and East Asia at the ASSA meetings in a U.S. city. Frequently no one in the interview room is from North America. The ASSA meetings also have a strong advantage in timing, occurring at about the latest possible moment to interview candidates prior to the winter "fly-back" season for hiring faculty in North American colleges and universities. The timing of the conventions of the other associations are either too early (Southern) or too late in the annual labor market season, and moving their convention closer to the annual ASSA meetings could be suicide for the regional associations.

\section{Survey Results}

To examine the demand for regional economic associations directly, I surveyed individuals who failed to renew their membership in the Midwest, Southern, and Western Economic Associations in the late $1990 \mathrm{~s}^{10}$. Out of the 808 surveyed members, 253 responded, 
for a response rate of 31 percent.

The respondents were asked four questions: (1) Why did you drop your membership in the regional economic association; (2) What did you substitute for membership in the regional association, if anything,; (3) What useful role, if any, do you believe a regional economic association can play today; and (4) What could the regional economic association do to persuade you to rejoin?

It is clear that former members dropped their membership primarily due to concerns about the annual convention rather than concerns about the associations' journals. As reported in Table 2, participation in the conference and the quality of conference papers and discussants constitute the overwhelming reasons for failing to renew.

Surprisingly few respondents identified the quality of the journal as a reason for dropping their membership. In the case of the Midwest association, it is not clear how many of the former members would have linked the Quarterly Review of Economics and Finance with the association because a subscription to the journal is independent of membership. More former Southern association members identified journal quality as motivating their decision. Because the editorship of the Southern Economic Journal changed in 1996, it is not clear whether respondents, who had dropped their membership over several years in the late 1990s, were referring to the old grey $\underline{\mathrm{SEJ}}$ or the new green post-1996 $\underline{\mathrm{SEJ}}$, however.

The one variable that is under direct control of the Boards of the associations is price--the convention registration fee (and associated submission fees) and annual member dues. As would be expected, the response frequency of "too expensive" grows in proportion to the level of dues and convention registration fees, rising from only two of 99 former members of the inexpensive Midwest to 17 of 108 former members of the higher priced Western. 
The former members of the associations were asked whether they had substituted something else for membership in the association. Although I anticipated that respondents would identify other economics associations, I also received listings for the local yacht club, the American Fisheries Society, the American Mathematical Association, and, perhaps one of the more forthright responses--leisure time. Of the 253 respondents 12 , the exact number who reported moving as the reason for dropping their membership, indicated that they joined a different one of the four established regional economics associations. Thirteen reported joining smaller regional economics associations or their state economics association. About 30, or only 12 percent, identified a wide variety of field specific associations or journals as substitutes for their membership in the regional economic association. One hundred ninety-eight of the respondents did not report substituting anything for their membership in the regional economic association.

Declining association membership does not appear to be related to explicit new forms of competition. Interestingly, it does appear related to the annual convention. This is interesting because, like the American Economic Association, with the exception of the Midwest, the regional associations do not require membership in the association to either attend or appear on the program of the convention. In the case of the Midwest, the modest membership dues are simply a (prerequisite) portion of the convention registration fee. I presume they have remained separate because for some reason, some people, including myself, continue to pay membership dues to the Midwest even when they do not attend the convention. Exactly what we think we are buying is an interesting question.

In the case of the other three regional associations, however, unlike the AEA, the conference registration fee is discounted for association members. The fact that economists who 
participate on the program can join the association at a discounted rate that year creates a link between association membership and the attraction of the annual convention. Also unlike the ASSA meetings, which attract about 8,000 registrants and include more than 3,000 different individuals on the program, the vast majority of registrants at the regional association meetings appear on the program. Thus, it is not unexpected to see that many drop their membership when their participation wanes.

The lesson to be learned from the survey seems to be that convention size, structure, and the connection of convention registration fees with association membership dues are important decisions for the long-term membership vitality of the regional associations. As can be seen in Table 3, the former regional association members see the annual regional conferences as significantly more important services than the regional associations' general interest economics journals, or, for that matter, anything else.

\section{Empirical Estimates}

It also is possible to investigate the demand for association membership and convention attendance directly. The American, Southern, and Western associations each produced a time series of both association membership and convention registration. I also secured annual convention registration numbers from the Midwest for most of the period between 1985 and 2000. Tables 4, 5, 6, and 7 report membership and conference attendance data, dues and registration fees, and other relevant information for selected years.

With these data I have estimated the demand for membership and conference attendance for the American, Southern, and Western associations, and the demand for conference attendance for the Midwest association, assuming supply to be perfectly elastic at the existing price. 
Because the elasticity of demand naturally should vary with the price level, I limited the time series for each estimate to a period that avoided substantial changes in the real price level ${ }^{11}$.

Membership. Ordinary least squares (OLS) membership equations for the American, Southern and Western associations, without any corrections for autocorrelation, are reported in Table 8. Because there is no theoretical basis on which to expect a particular functional form, I estimated them using both linear and logarithmic forms. Membership is hypothesized to depend on: (1) time, reflecting a secular trend, and (2) price $^{12}$.

The estimates indicate that membership in the AEA increases about 123 per year, WEA is stable, and SEA declines about 17 per year. The results imply that demand is inelastic for all three associations, which is plausible. The log-log estimates indicate an own-price elasticity of 0.25 for the American, -0.27 for the Southern, and -0.59 for the Western association. Each of these elasticity estimates is statistically significantly different from both zero and unity.

Not surprisingly in light of the level of dues relative to typical income levels of economists, it appears that price does not have a significant effect on membership levels. The associations could enhance their revenues, if they so wished, by raising dues.

Convention attendance. Comparable OLS estimates of convention attendance are reported in Tables 9 and 10. Convention attendance is hypothesized to depend on: (1) time, (2) price, or registration fee; and (3) the convention location. In addition, for the ASSA meetings, I control for those specific years early in the data period when the American Statistical Association was included in the meetings, the three years when the meetings were held in August or September, and the shift in 1993 from meeting between December 28-30 to meeting during the first weekend after January 2. 
The ASSA convention results reported in Table 9 suggest an upward trend in registration of 144 per year and no sensitivity of attendance to the registration fee. This is not surprising, as the ASSA registration fee has only recently been raised to $\$ 50$, and is a small fraction of the total cost of attending the convention.

The results indicate that the departure of the American Statistical Association from the ASSA meetings did not cause a significant drop in attendance. Nor did the move from the last week of December to the first week of January. The three experiments with an August or September meeting, however, were an attendance disaster, causing an expected decline in attendance of over 40 percent, ceteris paribus. Finally, in comparison with the average of the benchmark cities of Anaheim, Atlanta, Atlantic City, Dallas and Denver, which collectively hosted only 7 of the 28 conventions, New York and Washington DC attract about 1600 more registrants. This finding confirms anecdotal impressions of the convention staff.

Estimated attendance for the regional conventions is reported in Table 10. Unlike the ASSA meetings, there appears to be no trend in regional association convention registration. The own price elasticity of demand is very low, as only one of the six estimates is significantly different from zero, and that one (the log specification for the Southern convention) suggests an elasticity of only -0.35 . The relevant cities of course differ among the regional associations. Chicago raises attendance by 17 percent for the Midwest and Washington DC boosts attendance by 26 percent for the Southern. Location does not appear to affect attendance at the Western meetings. Whatever is important for the Western meetings is not captured well by the included variables, as less than a third of the variation in attendance is explained. Obvious omitted factors that likely affect attendance at all the association meetings include the size of the program and the entrepreneurial enthusiasm and marketing efforts of the staff. 
In contrast to association membership, which is declining for most of the regional associations and stable, at best, for the AEA, economic convention attendance appears to be stable (for the regional associations) or rising (for ASSA). The stable or upward trend in convention attendance may reflect "meet space." Although cyberspace seems to provide an alternative for face-to-face meetings at conventions, cyberspace also induces much more communication and increases the number of contacts with whom economists network. And, there appears to be a demand for face-to-face meeting of people whose first and perhaps only contact has been in cyberspace.

\section{Conclusion}

It is not obvious what to make of all this. The demand for less prestigious general interest economics journals appears to be waning, the demand for regional economics conferences is holding steady, and the price elasticity of demand for both regional association membership and convention registration is very low. Associations could raise sufficient revenues to stay in business.

So far as I can determine, there is no other study of the relative and absolute decline of the regional economics associations in the U.S. Perhaps that is because only the boards of the individual associations have any interest in their viability. Given the increasing mobility of economists, lower real transportation costs, the growth of field specific societies and journals, the Internet and its impact on the costs of communication among scholars of similar interests regardless of location, and the quest for national recognition by a wide array of institutions, including many that once were satisfied with an image as excellent regional colleges and universities, the future of regional economics associations does not look promising. It will take hard work and loyalty among a significant core of members to maintain their viability through 
the next several decades. They would do best to focus their attention on providing an annual convention that continues to attract participants. 
References

Ellison, Glenn, "The Slowdown of the Economics Publishing Process," National Bureau of Economic Research, Working Paper 7804 (July 2000).

Newey, Whitney and Kenneth West, "A Simple Positive Semi-Definite, Heteroskedasticity and Autocorrelation Consistent Covariance Matrix, "Econometrics (1987), Vol. 55, pp. 703708.

Noll, Roger, "The Business of College Sports and the High Cost of Winning," The Milken Institute Review (Third Quarter 1999), pp. 24-37.

Scott, Frank A. and Jeffrey D. Anstine, "Market Structure in the Production of Economics Ph.D.'s," Southern Economic Journal(July 1997) Vol. 64, No. 1, pp.307-320.

Siegfried, John J., "Who Is a Member of the AEA?" Journal of Economic Perspectives (Spring 1998) Vol. 12, No. 2, pp. 211-222.

Siegfried, John J. and Larry Nelson, "Minimizing AEA Convention Transportation Costs," American Economic Review (December 1979) Vol. 69, No. 5, pp. 983-988.

Siegfried, John J. and Wendy A. Stock, "The Labor Market for new Ph.D. Economists," Journal of Economic Perspectives (Summer 1999) Vol. 13, No. 3, pp. 115-134.

Siegfried, John J. and Wendy A. Stock, "So You Want to Earn a Ph.D. in Economics: How Long Do You Think It Will Take?" Journal of Human Resources (Spring, 2001).

Smythe, David J., "Where the Economists Are," Journal of Economic_Perspectives (Fall 1999), Vol. 13, No. 4, p. 271.

Thompson, L. A., R. M. Gaedeke, and D. H. Tootelian, "Professional Conferences--the Leisure of the Theory Class," Collegiate News Views (Winter 1977-78), Vol. 31, pp. 1-3.

Table 1. Regional Distribution of AEA Members, 1969 and 1997.

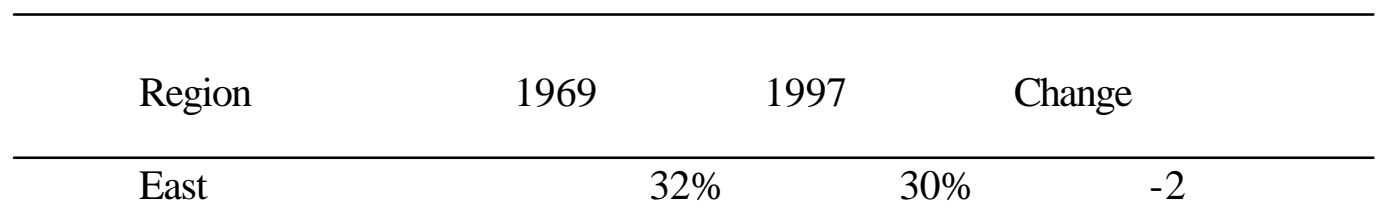




\begin{tabular}{|c|c|c|c|c|c|c|}
\hline Midwest & & 31 & & 25 & & -6 \\
\hline South & 21 & & 27 & & +6 & \\
\hline West & & 17 & & 19 & & +2 \\
\hline
\end{tabular}

Source: David J. Smyth, "Where the Economists Are," Journal of Economic Perspectives, (Fall 1999), p. 271.

Table 2. Reasons for Dropping Regional Association Membership

Midwest Southern Western

\begin{tabular}{|c|c|c|c|c|}
\hline Responses & & 99 & 50 & 108 \\
\hline Response rate & $33 \%$ & $26 \%$ & $33 \%$ & \\
\hline
\end{tabular}




\begin{tabular}{|c|c|c|c|c|c|}
\hline Didn't participate in conference & & $40 \%$ & $22 \%$ & $44 \%$ & \\
\hline Quality of conference papers/discussants & 13 & & 2 & 13 & \\
\hline Changed job and/or moved & & & 10 & 8 & 12 \\
\hline Retired & & & 9 & 10 & 6 \\
\hline Too expensive & & & 2 & 6 & 16 \\
\hline Overlooked renewal & & & 5 & 14 & 0 \\
\hline Quality of journal & & & 0 & 10 & 4 \\
\hline Insufficient interest in conference & 7 & 6 & 0 & & \\
\hline Employer would not reimburse & & & 3 & 4 & 4 \\
\hline Joined only for job market at conference & 1 & 4 & 0 & & \\
\hline Switched to AEA & & & 0 & 4 & 0 \\
\hline Unfriendly meeting environment & & 2 & 0 & 0 & \\
\hline Other & & & 8 & 10 & 3 \\
\hline
\end{tabular}

Percent reporting they substituted to $\quad 30 \% \quad 21 \% \quad 21 \%$ an alternative association

Source: Survey in Spring 2000 of recent discontinued members provided by each association. Four respondents to WEA survey provided two responses each. Otherwise number of responses equals number of respondents.

Table 3. What is a Useful Role for Regional Economics Associations?

Midwest Southern Western

$\begin{array}{llll}\text { Responses } & 99 & 50 & 104\end{array}$

Hold conferences to share papers $\quad 40 \% \quad 52 \% \quad 35 \%$ 
Network and interact with economists from the region

$28 \quad 26 \quad 20$

Publish a journal

$2 \quad 10 \quad 6$

Hold a job market

$\begin{array}{lll}3 & 2 & 0\end{array}$

Focus on research of special concern $\quad \begin{array}{llll}3 & 8 & 5\end{array}$

to the region

Faculty development

$2 \quad 0 \quad 1$

$\begin{array}{llll}\text { No response } & 22 & 2 & 33\end{array}$

Source: Survey in Spring 2000 of recent discontinued members provided by each association.

Table 4. AEA Membership and ASSA Convention Data, 1950-2001

\begin{tabular}{|c|c|c|c|c|c|c|c|c|}
\hline Year & $\begin{array}{c}\text { Total } \\
\text { Members* }\end{array}$ & $\begin{array}{l}\text { Nominal } \\
\text { Dues }\end{array}$ & $\begin{array}{c}\text { Real } \\
\text { Dues** }\end{array}$ & $\begin{array}{c}\text { New } \\
\text { Ph.D.=S } \\
\text { per } \\
\text { Year** } \\
*\end{array}$ & $\begin{array}{l}\text { Convention } \\
\text { Registration }\end{array}$ & $\begin{array}{c}\text { Nominal } \\
\text { Convention } \\
\text { Registration } \\
\text { Fee }\end{array}$ & $\begin{array}{c}\text { Real } \\
\text { Convention } \\
\text { Registration } \\
\text { Fee } * *\end{array}$ & $\begin{array}{l}\text { Convention } \\
\text { City }\end{array}$ \\
\hline 1950 & 6936 & 6 & 24 & 200 & 3458 & 1 & 4 & Chicago \\
\hline 1951 & 7068 & 6 & 23 & 223 & 2948 & 2 & 8 & Boston \\
\hline 1954 & 7486 & 6 & 22 & 245 & 2001 & 2 & 7 & Detroit \\
\hline
\end{tabular}


34

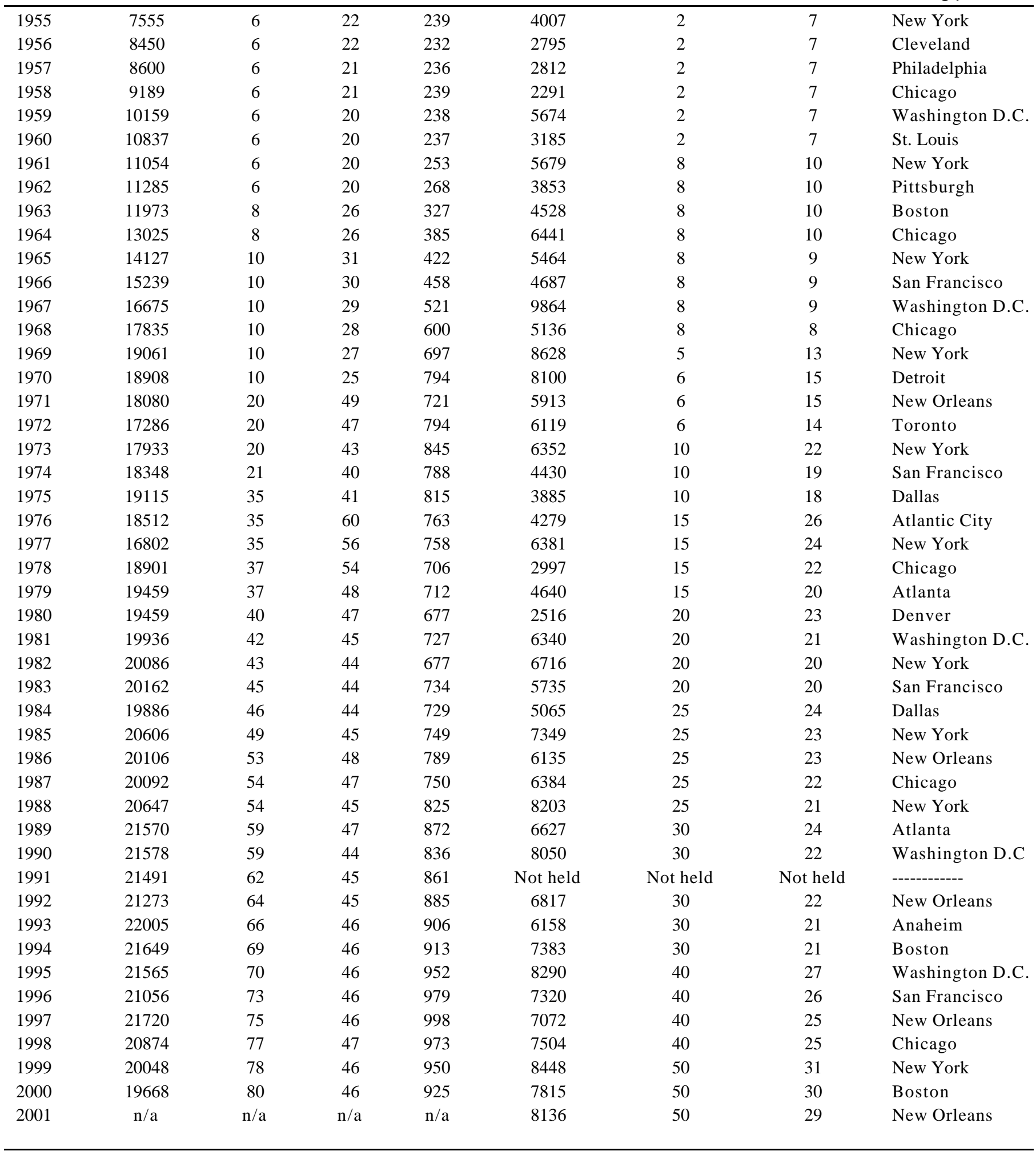

*regular, student, life, and honorary

**1982-84 dollars $=100$

$* * *$ for the years $58,60,62,64,66,70,72,74$ the average of the year before and the year after were used

$\mathrm{PhD}=\mathrm{s}$ for the year 1999 and 2000 were estimated. 
Table 5. SEA Membership and Convention Data, 1974-1999

\begin{tabular}{|c|c|c|c|c|c|c|c|c|}
\hline Year & Membership & $\begin{array}{c}\text { Nominal } \\
\text { Dues }\end{array}$ & $\begin{array}{c}\text { Real } \\
\text { Dues* }\end{array}$ & $\begin{array}{c}\text { Convention } \\
\text { Registration }\end{array}$ & $\begin{array}{c}\text { Nominal } \\
\text { Convention } \\
\text { Registration } \\
\text { Fee } \\
\end{array}$ & $\begin{array}{c}\text { Real } \\
\text { Convention } \\
\text { Registration } \\
\text { Fee } \\
\end{array}$ & $\begin{array}{c}\text { Convention } \\
\text { City } \\
\end{array}$ & $\begin{array}{c}\text { SEA } \\
\text { Members as } \\
\% \text { of Total } \\
\text { Registration } \\
\end{array}$ \\
\hline 1974 & 1501 & 10 & 19 & 827 & 5 & 10 & Atlanta & $\mathrm{n} / \mathrm{a}$ \\
\hline 1975 & 1619 & 12 & 22 & 642 & 10 & 18 & New Orleans & $\mathrm{n} / \mathrm{a}$ \\
\hline 1976 & 1636 & 14 & 24 & 849 & 10 & 17 & Atlanta & 87 \\
\hline 1977 & 1730 & 14 & 23 & 1103 & 10 & 16 & New Orleans & 76 \\
\hline 1978 & 1810 & 14 & 21 & 1239 & 10 & 15 & Washington & 71 \\
\hline
\end{tabular}




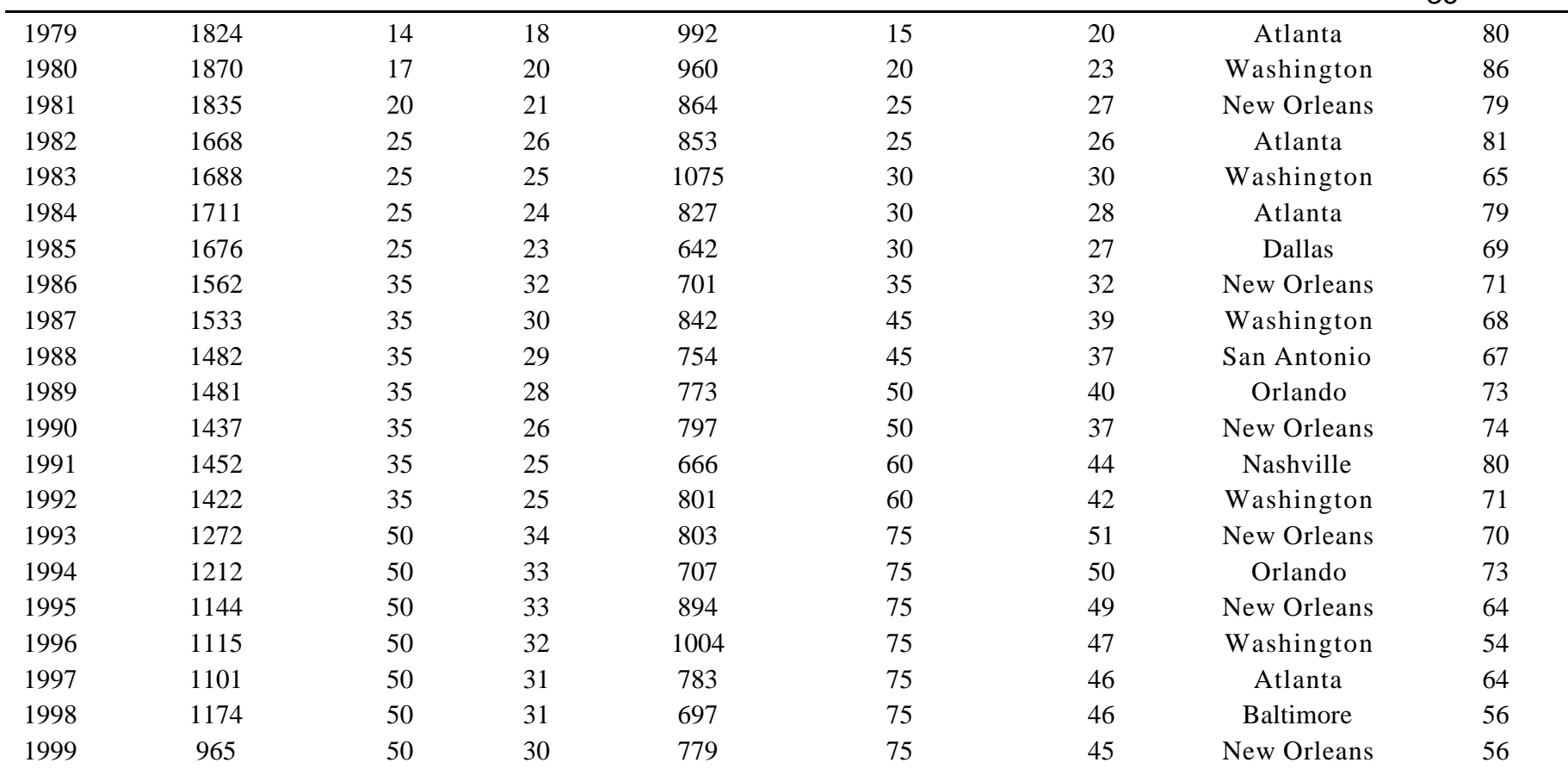

*1982-84 dollars $=100$

NOTE: Data for 1999 were not included in the regression because the responsibility of soliciting renewals was transferred to Allen Press, rendering the figures inconsistent n/a: not available

Table 6. WEA Membership and Convention Data

\begin{tabular}{|c|c|c|c|c|c|c|c|}
\hline Year & Membership & $\begin{array}{c}\text { Nominal } \\
\text { Dues }\end{array}$ & $\begin{array}{c}\text { Real } \\
\text { Dues* }\end{array}$ & $\begin{array}{c}\text { Convention } \\
\text { Registration }\end{array}$ & $\begin{array}{c}\text { Nominal } \\
\text { Convention } \\
\text { Registration } \\
\text { Fee } \\
\end{array}$ & $\begin{array}{c}\text { Real } \\
\text { Convention } \\
\text { Registration } \\
\text { Fee* } \\
\end{array}$ & $\begin{array}{c}\text { Convention } \\
\text { City } \\
\end{array}$ \\
\hline 1982 & 2286 & 35 & 36 & 821 & 50 & 51 & Los Angeles \\
\hline 1983 & 1979 & 45 & 44 & 678 & 75 & 74 & Seattle \\
\hline 1984 & 1775 & 50 & 47 & 653 & 75 & 71 & Las Vegas \\
\hline 1985 & 1595 & 55 & 50 & 698 & 75 & 69 & Anaheim \\
\hline 1986 & 1434 & 55 & 50 & 834 & 80 & 72 & San Francisco \\
\hline
\end{tabular}




\begin{tabular}{cccccccc}
\hline 1987 & 1519 & 40 & 35 & 816 & 80 & 69 & Vancouver \\
1988 & 1914 & 40 & 33 & 803 & 80 & 66 & Los Angeles \\
1989 & 2080 & 40 & 32 & 1045 & 85 & 67 & Lake Tahoe \\
1990 & 2160 & 40 & 30 & 1142 & 85 & 64 & San Diego \\
1991 & 2200 & 45 & 33 & 1153 & 88 & 64 & Seattle \\
1992 & 2303 & 45 & 32 & 1329 & 88 & 62 & San Francisco \\
1993 & 2334 & 50 & 34 & 964 & 90 & 62 & Lake Tahoe \\
1994 & 2450 & 50 & 33 & 1130 & 90 & 60 & Vancouver \\
1995 & 2135 & 55 & 36 & 988 & 90 & 59 & San Diego \\
1996 & 2200 & 55 & 35 & 973 & 95 & 60 & San Francisco \\
1997 & 2113 & 55 & 34 & 1096 & 95 & 59 & Seattle \\
1998 & 2060 & 55 & 34 & 947 & 95 & 58 & Lake Tahoe \\
1999 & 2002 & 60 & 36 & 1005 & 115 & 68 & San Diego \\
\hline
\end{tabular}

*1982-1984 dollars $=100$

Table 7. MEA Convention Data, 1982-2000Table 7. MEA Convention Data, 1982-2000

\begin{tabular}{ccccc}
\hline YearYear & $\begin{array}{c}\text { Convention } \\
\text { Registration }\end{array}$ & $\begin{array}{c}\text { Nominal } \\
\text { Convention } \\
\text { Charges* }\end{array}$ & $\begin{array}{c}\text { Real Convention } \\
\text { Charges** }\end{array}$ & Convention City \\
\hline 1982 & 428 & 5 & 5 & Chicago \\
1983 & 550 & 6 & 6 & St. Louis \\
1984 & N/A & 8 & 8 & Chicago \\
1985 & 363 & 16 & 15 & Cincinnati \\
1986 & 500 & 16 & 14 & Chicago \\
1987 & 360 & 16 & 14 & St. Louis \\
1988 & 430 & 16 & 13 & Chicago \\
1989 & 360 & 16 & 13 & Cincinnati \\
\hline
\end{tabular}




\begin{tabular}{ccccc}
\hline 1990 & N/A & 16 & 12 & Chicago \\
1991 & 360 & 16 & 12 & St. Louis \\
1992 & N/A & 26 & 118 & Chicago \\
1993 & 400 & 26 & 18 & Indianapolis \\
1994 & 400 & 30 & 20 & Chicago \\
1995 & 252 & 30 & 20 & Cincinnati \\
1996 & 346 & 40 & 25 & Chicago \\
1997 & 252 & 40 & 25 & Kansas City \\
1998 & 350 & 50 & 31 & Chicago \\
1999 & 326 & 45 & 27 & Nashville \\
2000 & 347 & 50 & 29 & Chicago \\
& & & & \\
\hline
\end{tabular}

* includes registration fee and membership fee

** 1982-1984 dollars $=100$

n/a: not available

Table 8. Estimated Demand for Association Membership

(Dependant variable is total individual membership)

\begin{tabular}{|c|c|c|c|c|c|}
\hline AEA & AEA & $\begin{array}{lcc} & \text { SEA } \\
\text { linear } \log \quad \text { linear } \log & \text { linear } \\
(1971-2000) \quad(1974-1998)\end{array}$ & $\begin{array}{l}\text { SEA } \\
\text { or } \log \\
(198\end{array}$ & $\begin{array}{r}\text { WEA } \\
-1999)\end{array}$ & WEA \\
\hline
\end{tabular}

Average membership $\quad 19,997 \quad 1,518$

2,030 
Time (per year) $123^{* *} \quad 0.01 * * \quad-17.2^{*}-0.01 * * \quad 4.9 \quad 0.00$

$\begin{array}{llll}(4.0) & (4.1) \quad(-2.3)(-2.5) \quad(0.3)(0.4)\end{array}$

Dues (in 1980-82 \$)-93.8** $-0.25^{* *}-18.9^{* *}-0.27 * * \quad-28.6 * *-0.59 * *$

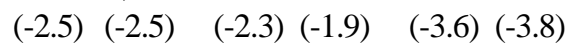

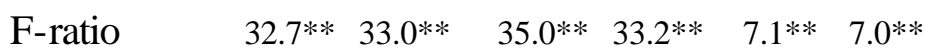

$\begin{array}{llllll}\text { Adjusted R Squared } 0.69 & 0.69 & 0.74 & 0.73 & 0.42 & 0.41\end{array}$

$\begin{array}{lllllll}\mathrm{n} & 30 & 30 & 25 & 25 & 18 & 18\end{array}$

In the log equations membership, dues, new Ph.D.s and retiring Ph.D.s are in logs; time is linear.

Equations estimated with an intercept that is not reported.

$*_{\text {significant at }}=.10 ; * *$ significant at $=.05$.

Table 9. Estimated Demand for AEA Convention Attendance

(Dependent variable is total conference registration)

(1973-2001)

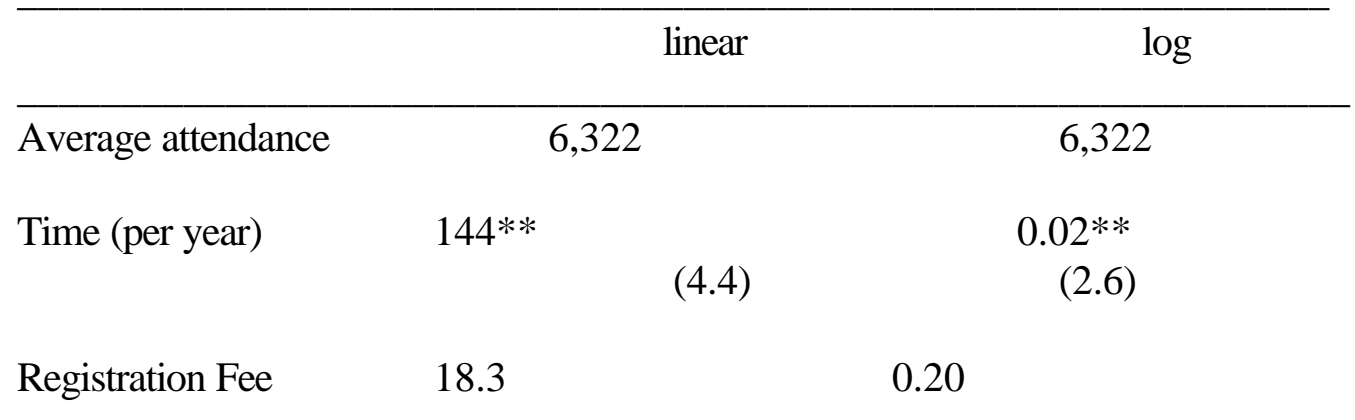




\begin{tabular}{|c|c|c|c|}
\hline (in 1980-82 \$) & & $(0.3)$ & $(0.7)$ \\
\hline Joint with AStatA & & 761 & $\begin{array}{l}0.13 \\
\quad(0.8)\end{array}$ \\
\hline August or Sept $(n=3)$ & $-1478 *$ & $(-3.2)$ & $\begin{array}{r}-0.44 * * \\
(-3.8)\end{array}$ \\
\hline January & & $\begin{array}{r}-398 \\
(-1.0)\end{array}$ & $\begin{array}{l}-0.07 \\
(-0.7)\end{array}$ \\
\hline Chicago $(n=3)$ & & $277 \quad(0.7)$ & $\begin{array}{l}0.06 \quad(0.6) \\
\end{array}$ \\
\hline New York $(n=6)$ & & $\begin{array}{r}1698 * * \\
(5.0)\end{array}$ & $\begin{array}{l}0.27 * * \\
(3.3)\end{array}$ \\
\hline Washington DC & $(\mathrm{n}=3)$ & $\begin{array}{l}1561 * * \\
(4.1)\end{array}$ & $(2.7)^{0.25^{* *}}$ \\
\hline New Orleans $(n=4)$ & & 479 & $\begin{array}{l}0.09 \\
\quad(1.0)\end{array}$ \\
\hline San Francisco $\quad(n=3)$ & 485 & (1.3) & $(0.9)$ \\
\hline Boston $(\mathrm{n}=2)$ & & 732 & 0.13 \\
\hline $\begin{array}{l}\text { F-ratio } \\
\text { Adjusted R Squared } \\
\qquad 28\end{array}$ & & $\begin{array}{ll}21.7 & \\
0.94 & \\
& 28\end{array}$ & $\begin{array}{l}13.0 \\
0.90\end{array}$ \\
\hline
\end{tabular}

(Table 9)

In the log equations attendance and fees are in logs; time, joint meeting with American Statistical Association, months, and city binary variables are linear (or $\operatorname{logs}$ in 1 and e). Intercept not reported; $\mathrm{t}$-ratios are in parentheses.

Benchmark cities: Atlanta, Anaheim, Atlantic City, Denver, Dallas.

$*$ significant at $=.10 ; * *$ significant at $=.05$. 
Table 10. Estimated Demand for Convention Attendance (Dependent variable is total convention registration)

\begin{tabular}{|c|c|c|c|c|}
\hline & & $\begin{array}{l}\text { MEA } \\
\text { linear log } \\
(1985-2000)\end{array}$ & 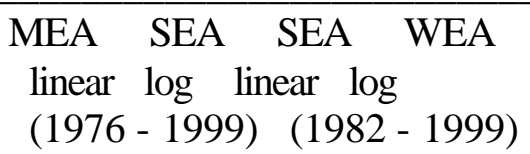 & WEA \\
\hline Average attendar & & 360 & 850 & \\
\hline Time (per year) & -7.2 & $\begin{array}{c}-0.02 \quad 2.1 \\
(-1.4) \quad(-1.3) \quad(0.2)\end{array}$ & $\begin{array}{lll}12.8 & 0.02 & \\
(1.1) & (1.3) & (1.6)\end{array}$ & \\
\hline Registration Fee & -2.0 & $-6.3-0.35^{* *}$ & $* \quad-9.84 \quad-0.65$ & \\
\hline
\end{tabular}




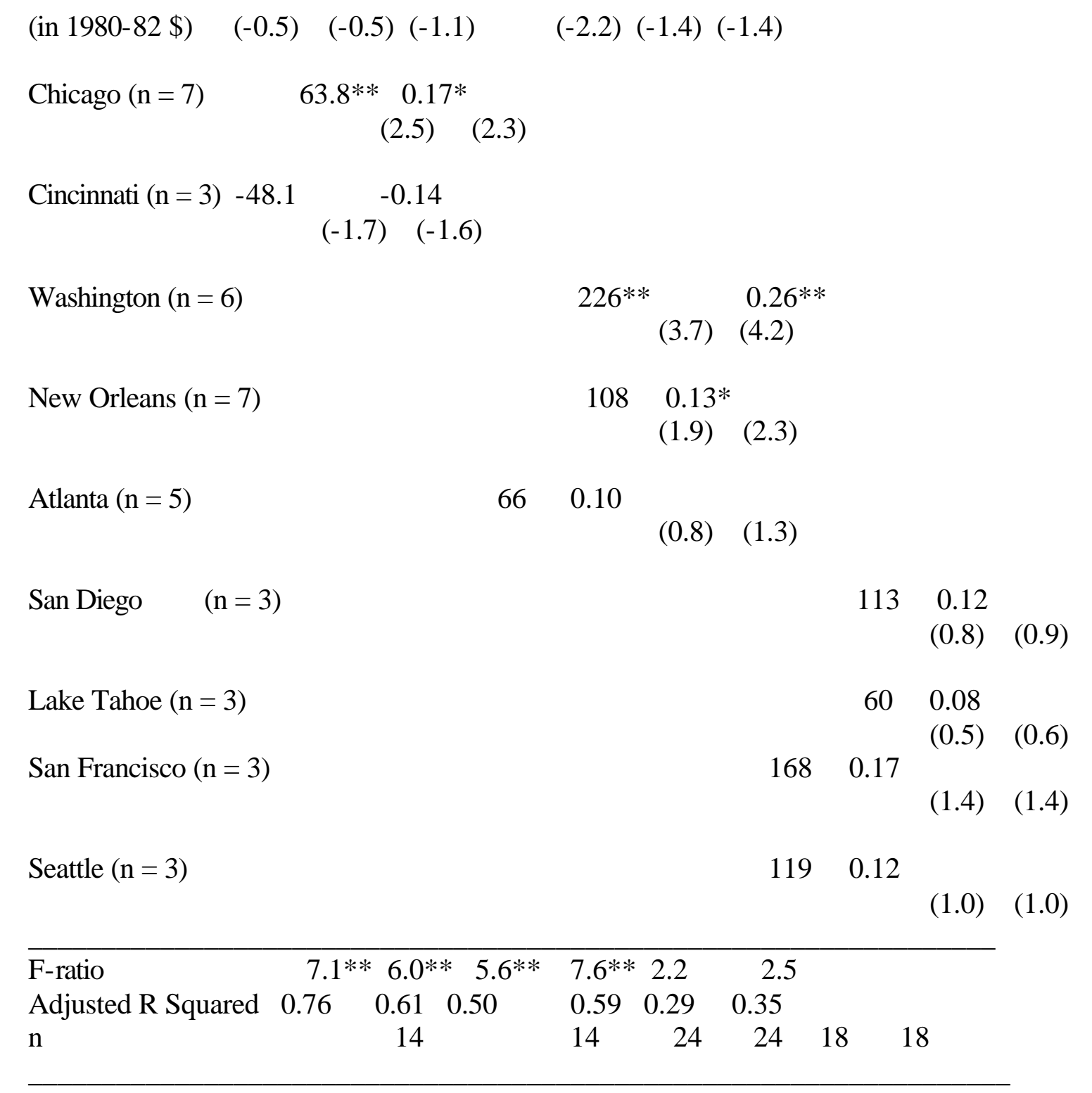

(Table 10)

In the log equations attendance and fees are in logs; time and city binary variables are linear (or logs in 1 and e).

Data unavailable for MEA for 1990 and 1992. Benchmark cities for MEA are: Nashville, Kansas City, St. Louis, and Indianapolis $(\mathrm{n}=5)$.

Benchmark cities for SEA are: Dallas, San Antonio, Orlando, Nashville, and Baltimore

Benchmark cities for WEA are: Los Angeles, Las Vegas, Vancouver, and Anaheim $(n=6)$.

Intercepts not reported.

$*$ Significant at $=.10 ; * *$ significant at $=.05$. 


\section{Endnotes}

\footnotetext{
1 Professional associations have affected my career. Not only does one of them now pay a portion of my salary, but each of the three American Economic Association (AEA) journals and each of the journals of the four established regional associations have published some of my articles. I also confess that each of those journals has rejected some of my submissions. I have attended all but two AEA conventions since 1971, and have attended each of the regional associations' conventions numerous times.

2 Since 1982, the Western association has published a second journal, Contemporary Policy Issues. It contains economic research and analysis on current issues of concern to business, government, and other decision makers, written so as to be accessible to readers with a limited background in economics.
} 
3 The Western also organizes a bi-annual international conference.

4 Membership data for the Eastern Economic Association are available only for the past five years. They show little change from a level near 700. Because the Eastern Economic Association was organized only in 1974 and at the beginning necessarily had just one member, the data would reveal an increase in its membership over the past few decades.

5 Those in Tennessee, Kentucky, and southern Indiana and Ohio seem comfortable with being simultaneously in both the South and the Midwest for the purposes of regional economics associations.

6 Although the AEA bylaws require nomination by an existing member, I can assure you that is not a challenging hurdle. As the current secretary-Treasurer and a member, I will nominate anyone whose check clears the bank.

7 These are also popular with the hotels, as you could easily determine on the basis of the prices charged for drinks.

8 About 40 percent of the audience in Cleveland on March 30, 2001 drove to the MEA meeting.

9 When I was department chair at Vanderbilt in the early 1980s we regularly interviewed prospective assistant professors at the Southern Economic Association meetings in November. Hardly any universities interview at the SEA meetings today.

10 The lists of dropped members were provided by the Secretary-Treasurers of the Associations.

11 Real AEA dues almost doubled from 1970 to 1971; the largest jump in the ASSA convention registration fee was in 1973. Thus I used the period 1971 through 2000 to estimate membership and 1973 through 2001 to estimate convention attendance for the AEA. Dues and registration fees for the Midwest meetings doubled from 1984 to 1985 so I began that series in 1985. Because there is no similar abrupt change in either membership dues or the convention registration fee for either the Southern or Western associations I used all of the data available for them, 1974 through 1998 for the Southern's membership and 1976 through 1999 for its convention attendance, and 1982 through 1999 for both the Western's membership and convention attendance.

12 Standard errors are corrected using the Newey-West (1987) procedure. 